Revue québécoise de droit international

Quebec Journal of International Law

Revista quebequense de derecho internacional

\title{
INTERNATIONAL ENVIRONMENTAL GOVERNANCE REFORM WITHIN THE UNITED NATIONS: SEEKING MORE SUSTAINABILITY TOWARDS AND BEYOND RIO + 20 EARTH ENVIRONMENT SUMMIT
}

\section{Sylvestre-José-Tidiane Manga}

Volume 23, numéro 2, 2010

URI : https://id.erudit.org/iderudit/1068403ar

DOI : https://doi.org/10.7202/1068403ar

Aller au sommaire du numéro

\section{Éditeur(s)}

Société québécoise de droit international

ISSN

0828-9999 (imprimé)

2561-6994 (numérique)

Découvrir la revue

Citer cet article

Manga, S.-J.-T. (2010). INTERNATIONAL ENVIRONMENTAL GOVERNANCE REFORM WITHIN THE UNITED NATIONS: SEEKING MORE SUSTAINABILITY TOWARDS AND BEYOND RIO + 20 EARTH ENVIRONMENT SUMMIT. Revue québécoise de droit international / Quebec Journal of International Law / Revista quebequense de derecho internacional, 23(2), 209-224.

https://doi.org/10.7202/1068403ar
Résumé de l'article

Nous sommes à la veille du Sommet de Rio + 20 de 2012. La réforme institutionnelle attendue en gouvernance environnementale au sein des Nations Unions, porte pour l'heure, essentiellement sur les moyens administratifs que la communauté internationale compte se donner pour rendre efficiente la gestion administrative coordonnée de la multitude de structures que compte désormais le Programme des Nations Unies pour l'environnement. Cette recherche apprécie les travaux du Groupe Consultatif des Ministres de l'environnement sur la Gouvernance environnementale mondiale. Elle attire toutefois l'attention sur le fait que, pour assurer un avenir confortable au développement durable, l'Organisation mondiale de l'environnement (OME), dont la création est annoncée au coeur de l'agenda du Sommet de Rio +20 , doit être dotée de deux organes principaux qui pourraient contribuer amplement à induire un véritable mécanisme institutionnel générateur de développement durable. Le premier organe est à vocation scientifique. C'est l'Organe scientifique de l'OME qui devra avoir comme mission de mesurer, quantifier et adopter les indicateurs du développement durable tels que les seuils de production ou d'émission, les standards et taux environnementaux, les méthodes d'évaluation et de gestion des risques environnementaux et autres indices d'exploitation durable des ressources naturelles et génétiques. Le second devra être investi d'une mission de surveiller la mise en oeuvre des standards de développement durable adoptés par l'Organe scientifique de l'OME, et ce dans un contexte institutionnel bien organisé de résolution des différends environnementaux. Il s'agit de l'Organe de résolution des différends de l'OME. Enfin, la présente contribution en appelle à la bonne volonté politique pour mettre en oeuvre de tels changements institutionnels au Sommet de Rio 2012. Le manque de volonté politique est en effet, présenté comme pouvant potentiellement nuire à l'adoption de telles conditions idéales à l'avènement du développement durable. 


\title{
INTERNATIONAL ENVIRONMENTAL GOVERNANCE REFORM WITHIN THE UNITED NATIONS: SEEKING MORE SUSTAINABILITY TOWARDS AND BEYOND RIO + 20 EARTH ENVIRONMENT SUMMIT
}

\author{
SyLVESTRE-José-Tidiane MANGA*
}

\begin{abstract}
The International Environmental Governance reform expected soon within the United Nations system is the main point of the 2012 Rio +20 Summit Agenda. The challenge, as currently presented by the Consultative Group of Ministers on IEG, is to lay down the foundation leading to the establishment of a World Environment Organization able to produce efficiency in the coordination of the multitude of agencies which now belong to UNEP. This paper acknowledges the achievements of the Consultative Group of Ministers. It aims however to show that such an administrative reform may be able to improve IEG in terms of administration efficiency and accountability but has unfortunately a very limited effect in ensuring enough sustainability towards and beyond Rio +20 . It is therefore suggested the creation of a WEO with two key bodies able to bring in more sustainability. The first body is the WEO Scientific Body. Its mandate will be to measure and adopt sustainable standards, rates and limits of production or emission, methodologies and harmonization of methodologies on risks assessment and management, and any kind of sustainable indicators. The second is the WEO Disputes Settlement Body with a mission of implementing and applying the sustainable indicators measured and adopted by the WEO Scientific Body. This contribution to IEG improvement for more sustainability came to the conclusion that there are enough suitable conditions gathered and assets under UN current scientific activities for these changes to take place. It is therefore on the basis of such a potential to ensure more sustainability at the coming global environmental governance reform that this contribution calls for the political goodwill which is here presented as the main asset of sustainability in IEG.
\end{abstract}

Nous sommes à la veille du Sommet de Rio +20 de 2012. La réforme institutionnelle attendue en gouvernance environnementale au sein des Nations Unions, porte pour l'heure, essentiellement sur les moyens administratifs que la communauté internationale compte se donner pour rendre efficiente la gestion administrative coordonnée de la multitude de structures que compte désormais le Programme des Nations Unies pour l'environnement. Cette recherche apprécie les travaux du Groupe Consultatif des Ministres de l'environnement sur la Gouvernance environnementale mondiale. Elle attire toutefois l'attention sur le fait que, pour assurer un avenir confortable au développement durable, l'Organisation mondiale de l'environnement (OME), dont la création est annoncée au cœur de l'agenda du Sommet de Rio +20 , doit être dotée de deux organes principaux qui pourraient contribuer amplement à induire un véritable mécanisme institutionnel générateur de développement durable. Le premier organe est à vocation scientifique. C'est l'Organe scientifique de l'OME qui devra avoir comme mission de mesurer, quantifier et adopter les indicateurs du développement durable tels que les seuils de production ou d'émission, les standards et taux environnementaux, les méthodes d'évaluation et de gestion des risques environnementaux et autres indices d'exploitation durable des ressources naturelles et génétiques. Le second devra être investi d'une mission de surveiller la mise en œuvre des standards de développement durable adoptés par l'Organe scientifique de l'OME, et ce dans un contexte institutionnel bien organisé de résolution des différends environnementaux. Il s'agit de l'Organe de résolution des différends de l'OME. Enfin, la présente contribution en appelle à la bonne volonté politique pour mettre en œuvre de tels changements institutionnels au Sommet de Rio 2012. Le manque de volonté politique est en effet, présenté comme pouvant potentiellement nuire à l'adoption de telles conditions idéales à l'avènement du développement durable.

Legal Research Fellow, McGill University affiliated Centre of International Sustainable Development Law (CISDL). Principal International Consultant to the Convention on Biological Diversity Cartagena Protocol on Biosafety Parties (UNEP-GEF BIOSAFETY Unit). UNEP/CBD Member of Rosters of Experts on Biodiversity and Biosafety. 
Industrialisation and intensive production have brought wealth to populations on earth and to peoples in many ways and in many lands since the industrial revolution. However, the human race has shown throughout the last centuries its lack of balancing wealth achievements and natural and genetic resources conservation. We are today facing one of the most trying and crucial ages of history on earth as scientists are shedding more and more light on the negative consequences of our failure to conduct a sustainable behaviour for sustainable development in exploiting resources around us. It is more than due time to rethink our ways of exploiting natural and genetic resources on our lands and to revisit our policies and laws implementing the guidelines of the United Nations Commission on sustainable development (CSD). The CSD was established by the United Nations General assembly in December 1992 to ensure an effective follow-up to the United Nations Conference on environment and development (UNCED), also known as the Earth summit. The CSD is the highlevel forum for sustainable development within the United Nations system. The main current goals of the CSD are mainly the integration of the social, economic and environmental dimensions of sustainable development in policy-making at international, regional and national levels, the widespread adoption of an integrated, cross-sectional and broadly participatory approach to sustainable development and the measurable progress in the implementation of the goals and targets of the Johannesburg plan of implementation. ${ }^{1}$

It was at the 1972 United Nations conference on the human environment where a structure of an international environmental regime was first adopted with clear objectives and functions. Such an achievement led later that same year to the creation of the United Nations environmental programme (UNEP). Since then and through multilateral negotiations, many International environmental agreements (IEAs) have been adopted along with secretariats to run them. At the 1992 Rio Earth summit two environmental conventions were adopted on biodiversity and on climate change along with a third convention on desertification negotiated to be finally adopted in 1994. It was also at the Rio Earth summit where the financial component of IEG was achieved with the creation of the Global environment funds (GEF) as well as the CSD. ${ }^{2}$

It has not been long after these early smoothly coordinated achievements that IEG started to become a heavy and complex mechanism with the creation of a multitude of environmental agencies, programmes, initiatives and entities all connected to UNEP with different funding sources. Environment being itself a crosscutting area, inter-agency approaches became an important aspect of IEG. This

\footnotetext{
Report of the Governing Council on the Work of its Fourteenth Session, Doc. Off. AGNU, 42e sess., supp. n²5, Doc. NU A/42/25 (1987).

2 According to the World Commission on Environment and Development, "sustainable development requires the promotion of values that encourage consumption standards that are within the bounds of the ecologically possible and to which all can reasonably aspire" Ibid. Also according to the Sustainable Development Commission of the UK government, "Sustainable development is development that meets the needs of the present, without compromising the ability of future generations to meet their own needs", See U.K., Sustainable Development Commission, "What is sustainable development", online: sd-commission <http://www.sd-commission.org.uk/pages/what-issustainable-development.html>.
} 
situation has brought huge challenges to the administration of environmental activities within the UN system at a point where there is an obvious need for reform.

It is in such a context that we should understand the creation of the Consultative group of ministers or high-level representatives on IEG established by a decision of the 2009 UNEP governing council. After three years of work, the Consultative group of ministers seems to take a common stand towards the creation of a World environment organization (WEO) within the UN system with a main focus on solving the administration problems to bring more efficiency and accountability in environmental issues management.

This paper aims to further the work of the Consultative group of ministers by encouraging a suitable institutional reform able to ensure more sustainability in IEG. It does not consist of another argumentation in the current literature on the necessity of a WEO since the Consultative group of ministers is now working on diplomatic procedures toward a UN General assembly resolution to create the WEO. Rather, this contribution is a proposal of a set of key institutional reform elements to ensure more sustainability through the main coming reform aspects of IEG expected on efficiency and accountability for the purpose of strengthening administration within the UN system. It is expected that the WEO constitutive declaration not only provides a suitable organizational chart with classical organs such as a secretariat for administration or a plenary body in which member states will be represented, but also adopts clear mandates on how negotiation should be carried out to establish each one of those bodies. Therefore, this research will not develop administrative issues. Likewise, issues related to competency for a WEO or analysis on compliance between the WEO and any other UN organization will not be addressed in this present research. This procedure will allow us to reach our goal of proposing a couple of institutions able to guarantee more sustainability within the administrative reform expected, namely a WEO scientific body and a WEO disputes settlement body.

Our modest knowledge on procedures in multilateral negotiations allows us to say that such bodies will be first adopted in the charter of the WEO within the constitutive declaration. However, it is through multilateral negotiations that special working-groups will be constituted and be given a mandate to negotiate specific missions for those bodies. Such negotiations can easily take several years and will be adopted by the plenary body of the WEO.

This contribution will be carried out in three parts. The first part will support the importance of administrative efficiency and accountability in the expected reform as addressed by the Consultative group of ministers in the current literature on the topic and in international relations trends. The second is a call for more sustainability towards and beyond the Rio +20 Earth summit. The third is a suggestion of two potential options on the timing and schedule for multilateral negotiations in view of the WEO establishment after the Rio+20 summit. 


\section{ADMINISTRATIVE EFFICIENCY: A KEY ISSUE IN THE COMING REFORM ON INTERNATIONAL ENVIRONMENTAL GOVERNANCE}

International environmental governance has been a concern for the international community since the very early days of the sustainable development policy. It has recently become such a priority that a Consultative group of ministers has been created to suggest reforms for the improvement of efficiency and accountability in the world environmental governance toward and beyond the Rio +20 Earth summit.

In fact, the Consultative group of ministers or high-level representatives has been established by the governing council of the UNEP at its February 2009 25th session to consider a broader reform of the IEG system within the UN. ${ }^{3}$ The meeting of the Consultative group held in Belgrade in June 2009 was the first to initiate a dynamic focus on substantial reform of the IEG which is known today as the Belgrade process. ${ }^{4}$ Dr. Oliver Dulic, minister of environment and spatial planning of Serbia who acted as the President of the Governing council in Belgrade took the opportunity to remind the Consultative group that Rio +20 was the prospect of the Belgrade process. He stated indeed that "For the first time in many years there is a chance to make headway on international environmental governance as part of the ongoing climate change negotiations and the count-down to a possible Rio +20 in 2012." The followed meetings of the Consultative group of ministers or high-level representatives on IEG over the past two years kept taking the same stand and are allowing the international community and UNEP to progress on the issue as the reform of the IEG regime appears increasingly urgent.

In this section, we aim to show that administrative efficiency is a key issue in the coming reform on international environmental governance.

\footnotetext{
Consultative Group of Ministers or High level Representatives on International Environmental Governance. Draft 'Roadmap' on the Implementation of UNEP Governing Council Decision SSXI/1 on International Environmental Governance, UNEPOR, $1^{\text {st }}$ Sess., (2010).online: $<\mathrm{http} / / / \mathrm{www}$. rona. unep.org/documents/partnerships/IEG/Draft_Roadmap_on_IEG.pdf $>$. See also: United Nations environment programme, Press statement, online: <http://www.environment.go.ke/images/ speechesminister/environmentgovernments.pdf $>$. Read also: Rio +20 and the Future of International Environmental Governance, World Economic Forum, Discussion Paper, (2011) online: $<\mathrm{http}: / /$ www.unep.org/environmentalgovernance/Portals/8/Rio+20\%20Discussion\%20Paper\%20V2.pdfs

4 A summary of these two pre-meetings of the IEG consultative group and on the 'Belgrade process' can be found at: - UNEP/Consultative Group of Ministers or High-level Representatives, Second Meeting of the Consultative Group of Ministers or High-Level Representatives on International Environmental Governance, Espoo, Finland, 21-23, November 2010. See also: UNEP Consultative Group of Ministers or High-Level Representative OR, 2010, 2d Meeting, Nairobi-Helsinki Outcome, online: $<$ http://www.unemg.org/Portals/27/Documents/Cooperation/IntEnvGov/Nairobi\%20Helsinki\%20final \%20outcome\%20edited.pdf $>$.

5 Biljana Ledenican, Timeline Events/The Belgrade Process on International Governance, Innovation, Sustainability, Development, online: A New Manifesto <http://anewmanifesto.org/timeline/thebelgrade-process-on-international-environmental-governance/>.
} 


\section{A. Administrative Reform for a More Efficient and More Accountable IEG Towards Rio $+\mathbf{2 0}$}

The current debate on IEG reform has, over the past years, generated discussions and exchanges between states. Those have brought more light on the state of achievements and progress regarding the UNEP mandate on IEG as set out in UN General assembly resolution 2997 (XXVII) of 1972. The debate also helps to meditate on the matter in order to make the best choices in view of sustainability for a brighter future on IEG. Although discussions and exchanges are still ongoing, it seems, however, that there is a common need to find a more efficient IEG system to manage the multitude of intergovernmental bodies, secretariats, funds and inter-agencies mechanisms which have grown so fast in number since the creation of UNEP. On January 28, 2011, UNEP released a reference document where it is mentioned that "there are now more than 500 international treaties and other agreements related to the environment, of which 323 are regional and 302 date from the period between 1972 and the early 2000s." ${ }^{6}$ This official document was prepared to serve as a key "input to the work of the Governing council/global ministerial environment forum on broader reform of the international environmental governance system and the preparatory process for the United Nations Conference on sustainable development, to take place in Brazil in 2012."7 The international community nourishes great expectations from this coming event, also named Rio+20, which is planned to produce a huge step toward the improvement of the IEG. Considering the importance of challenges to be faced at Rio +20 environmental summit, UNEP has made available within this very document, nine main reasons or facts to justify the need to bring administrative reforms to the IEG. The headlines of those facts were summarized by UNEP in the document as follow:

1. Environment was acknowledged as a UN system-wide development challenge and opportunity already in the 1972 UN Conference on the Human Environment in Stockholm.

2. Environmental activities in the UN, has grown organically in response to emerging environmental problems and the evolution of the international environmental governance (IEG) system.

3. Environmental activities have over the past four decades increasingly become an integral component of the wider UN system intrinsically linked with activities in a broad range of areas and reflecting a growing importance attributed to the environment by various governing bodies across the system.

4. A significant number of UN institutions are involved in acquisition of environmental information through research, modelling, monitoring and observations, and the UN system has been at the forefront in developing international environmental assessment.

\footnotetext{
UN, Environment in the United Nations, note by the Executive Director, Governing Council/Global Ministerial Environment Forum, UNEP/GC.26/INF/23 Governing Council of the UNEP, Nairobi, 28 February 2011, Kenya. 
5. There are now more than 500 international treaties and other agreements related to the environment, of which 323 are regional and 302 date from the period between 1972 and the early 2000s.

6. A number of UN system entities are involved in efforts to ensure a responsive and cohesive approach to meeting country needs through capacity-building, technology support, the provision of financial support, training, enhancement of centres of excellence, promotion and support of South-South cooperation, exchanges of best practices and lessons learned, and development of partnerships and networks.

7. It is, today, difficult to assess the total amount of resources which is invested in environmental activities at normative and operational level in the UN system.

8. Effectiveness, efficiency and coherence within the UN system are in principle achieved through a mix of system-wide intergovernmental, financial and knowledge management measures coupled with interagency cooperation.

9. The UN system, represented by its programmes, agencies, secretariats and its coordinating mechanisms, collectively constitutes a unique compilation of institutional capacity for addressing environmental change. ${ }^{8}$

Those motives to justify needs to reform the IEG administrative system were faithfully carried out at the Nagoya biodiversity 2010 conference by the ministers of the environment of Finland and Kenya. Those two top-administrators, co-chairs of the Consultative group of ministers and/or high-level representatives, played a leading role in the whole process of IEG system improvement. At Nagoya, both clearly presented the option of a WEO to be the best option with a full potential to face the administrative challenges on IEG.

However though relevant those grounds of justification may be, they seem to be calling only for new institutional strategies, structures and mechanisms to solve administrative difficulties by administrative reforms. Nevertheless, since the Rio +20 expectations are big on this issue, should we not ask ourselves if the administration reform for more efficiency and more accountability is, in fact, the only problem hindering current trends in IEG to produce the sustainability and the ambitions targeted at the 1992 Rio Erath summit? Are there other challenges of this order? If so, how can we deal with them along with the administration issues in order to prepare the Rio +20 rendez-vous?

There is no doubt that the current debate on IEG has led to a unanimous conclusion of a need of administrative reform. However, in order to increase the outcome of the Rio+20 Agenda on IEG, the following section points to some of the other issues that need to be considered along with the administration target. Such matters bring another focus on dealing with an institutional reform to carry out more sustainability within the UN global reform expected on IEG. 


\section{B. More efficient institutional reform towards more sustainability}

There are two main reasons why the current main focus on the administrative reform in IEG deserves all our admiration and encouragement. The first is that the expected reform will surely allow more efficiency in the management of all the activities within the multitude of environmental agencies. The second is that the administrative reform will bring more accountability. In fact, IEG could be back on rails for a brighter future if the international community successfully takes a stand at the end of the Rio +20 summit for a WEO able to fix mandates as for which agency does what and which other one should be held responsible for results in each sustainable development activity. Nevertheless, it is not only the merging or the dislocating of environmental units and agencies that can ensure sustainability, which should be the raison d'être of IEG.

When Madam Rosa Aguilar Rivero, Spanish minister for the environment, rural and marine affairs was newly elected President of UNEP's Governing council, she supported that the efforts to strengthen International Environmental Governance should be about more than rationalizing of fragmentation and seeking efficiencies instead it should be about re-envisioning and even dreaming about what is required institutionally for environment and sustainability, and putting this in place. ${ }^{9}$ No doubt that sustainability is indeed the main issue of International environmental governance.

A careful reflection on the objectives and functions of IEG as stated at the Rio 1992 Earth summit will remind us that sustainability is one of the major targets for efficiency in sustainable development policy. Therefore, it appears to us that after having the focus on administrative efficiency through the last past years of planning and organizing Rio +20 , the international community should from now on give also more consideration to sustainability towards and beyond Rio +20 . The expected UN institutional reform with the WEO in perspective should indeed make more room to sustainability in view of reinforcing efficiency and accountability through administrative reform.

The second part of this paper will give us more details on suitable and practical proposals on how to ensure sustainability through the expected WEO charter.

\section{A CALL FOR REFORM: ELEMENTS IN FAVOUR OF MORE SUSTAINABILITY IN INTERNATIONAL ENVIRONMENTAL GOVERNANCE TOWARDS AND BEYOND RIO + 20}

This research states that in order to fully reach the expectations on sustainability towards and after Rio +20 , the international community might support

\footnotetext{
$9 \quad$ Government of Finland, International Environmental Governance Needs a real Reform, online: Energy
} Enviro Finland <http://www.energy-enviro.fi/index.php?PAGE=5\&PRINT=yes\&ID=3541>. 
the undergoing administrative reform with the creation of two main institutions which have a potential to add sustainability to administrative reform for a suitable and perennial change in IEG. These two institutions will be strategically positioned within the coming WEO. The first one is a scientific body (WEO SB) and the second one is a disputes settlement body (WEO DSB).

The WEO SB will receive the mission to establish and adopt environmental standards, quotas, limits of production or emission, methodologies and their harmonization and all other scientific tasks. The WEO DSB will be given a mission to watch over the implementation and the application of the WEO SB output through adapted disputes resolution mechanisms to any kind of disputes that may arise.

We believe that these two WEO bodies will be key instruments to produce sustainability beside administrative efficiency towards and after Rio +20 . Moreover, this contribution will ground the feasibility of the establishment of such bodies on institutional reform precedents and on the availability of both the human and technical potential within the UN institutional system and in the scientific world.

\section{A. A Scientific Body within the World Environment Organization (WEO Scientific Body)}

The scientific issue has already been of interest to the co-chairs of the Consultative group of ministers on IEG. It has even been the first recommendation among a total of six that Finland and Kenya handled to the UNEP governing council at its 26th session on February, 2011. Even though the matter interested the co-chairs on its developmental angle, it is more than appreciable to notice that science, which is one of the key functions of IEG since the 1992 Rio Earth summit, was in the center of their preoccupation. In fact, the recommendation on science cooperation was presented as follow: "enhance mutual communication between scientific panels and networks, and improve the availability of information on the environment and its use in political decision-making, especially in developing countries." ${ }^{10}$ However, the current contribution wishes that the issue of science function on IEG might be more put into contribution in the coming reform on IEG for the sake of sustainability.

It became obvious that the International community has been accumulating failures over the years mostly because of disagreements on quotas, standards, rates, methodologies and other scientific measurements facts, production, emission, etc. ${ }^{11}$ These failures have had huge negative impacts on multilateralism. This paper shares the conviction that conferences of the Parties and those so called International

10 Finland, Kerstin Stendahl and Ekman Hanna, Nairobi-Helsinki Outcome: Six Methods of reinforcing international environmental governance, Ministry of the environment (2011), online: Finnish Government <http:/www.valtioneuvosto.fi/ajankohtaista/tiedotteet/tiedote/en.jsp?toid=299567\&c=0\& moid $=299580$ \&oid $=322566>$.

11 It is sadly true that the implementation of international treaties such as the Montreal Protocol, the $U N$ Framework Convention on Climate Change and the Cartagena Protocol on Biosafety among many others has been very weak and slow mainly because of disagreements on rates, quotas, environmental risks methodologies, etc., where harmonization is much needed for the sake of sustainability. 
negotiations events are not the most suitable forums to host multilateral discussions on pure scientific measurement of sustainable quotas, rates, standards or methodologies. Therefore, the announced WEO should host a scientific body with a full authority to deal with sustainable scientific measurements to ensure sustainability. ${ }^{12}$ Environment being a global issue there should be transparency in the composition of such a body. The selection of scientists should be based on their scientific potential but also on their impartiality, integrity, dedication and commitment to sustainable development and to sustainability in natural resources management and genetic resources utilisation.

\section{The Human Resources Potential is Available for the WeO Scientific Body}

The potential of the WEO scientific body in terms of human resources will be found in the variety of backgrounds and the integrity of the many valuable and hard working scientists already involved in the activities of the UNEP scientific advisory groups such as the Ecosystems conservation group (ECG), the Intergovernmental panel on climate change (IPCC), the Joint group of experts on scientific aspects of marine protection (GESAMP), the Scientific and technical advisory panel (STAP), the United Nations scientific committee on the effects of atomic radiation (UNSCEAR), the International resource panel (IRP), etc. Many of those are representatives of the civil society which should be an active partner of the $\mathrm{UN}$ in the creation and the exploitation of the WEO SB. It is now known that sustainable economic activities can also imply a transparent work where experiences and competences of civil society will also be legitimated. ${ }^{13}$

It is not only the human resources potential, which assures us of the effectiveness of a WEO SB. There is also an institutional precedent within the UN system that can encourage the International community to take advantage from the creation of such an institution.

2. There is an Institutional Precedent to Support the Potential Creation of the WEO SB

Establishing a WEO scientific body to ensure sustainability on IEG will not constitute an institutional burden to the International community and the UN. There is already a body within the UN system which can serve as a precedent and as an example for the administrative structure needed for the WEO SB and its mission. We want to name the Codex alimentarius. This UN organization is carrying out a strategic

12 This contribution may give the impression to hold a strong position toward sustainability through the scientific body proposal. It should be however understood that such a body would in any way be perceived as a repressive institution. Rather, it is a key element of an institutional reform proposal pursuing a mission of contributing to a global process of harmonization of measurements, standards, methodologies, quotas and other production indices to ensure sustainability.

13 See David L. Levy \& Peter J. Newell, The Business of Global Environmental Governance (Cambridge: Massachusetts Institute of Technology Press, 2005). 
work both for the World health organization (WHO) and the World organization for food and agriculture (FAO). In fact, those two UN organizations felt in the past a great need of transparency and efficiency as they faced challenges in food safety and public health. The political good will and willingness of their members parties led them to jointly establish the Codex alimentarius with the noble mission to adopt standards for the implementation of their different programs. Those standards are then quantified, measured, fixed and brought into contribution for food safety and public health. On the official website of the Codex alimentarius, we can learn more about the mission of the organization which is quoted as below:

The Codex Alimentarius Commission was created in 1963 by FAO and WHO to develop food standards, guidelines and related texts such as codes of practice under the joint FAO/WHO Food Standards Programme. The main purposes of this programme are protecting health of the consumers and ensuring fair trade practices in the food trade, and promoting coordination of all food standards work undertaken by international and non-governmental organizations ${ }^{14}$.

The current contribution wishes that a similar collective need may be felt by the International community in order to agree on the necessity to have a SB under the announced WEO with a similar mission for the sake of sustainability.

The WEO SB will work in close collaboration with another WEO proposed body dedicated to disputes settlement. For the sake of sustainability, these two bodies will join their efforts in the broader context of the implementation of norms, standards, rates, quotas, methodologies and harmonized methodologies, limits of production or emission and other sustainable data quantified, estimated and fixed through sound scientific and technical procedures.

\section{B. A Disputes Resolution Body for Sustainable Development within the World Environment Organization (WEO Disputes Settlement Body)}

Disputes settlement in sustainable development is a topic with a blank agenda within the UN system global agenda. The subject is more than ignored not because of its lack of relevance but rather because of its potential impacts on free trade and economical liberalization. This reality is the main source of ongoing conflicts between WTO activities and sustainable development policy.

In reality, WTO has been favoured by International global governance in hosting a Disputes settlement body to conduct its mission to promote free trade. On the other hand, the UN environmental program, which is in charge of sustainable development within the UN system, fails to conduct its mission to preserve biodiversity mostly because of a lack of a DSB able to ensure sustainability. Moreover, it has become obvious to all trade law specialists in the world that the WTO disputes settlement body (WTO DSB) is not adequately specialized to produce

14 FAO/WHO Food Standards Programme, Codex Alimentarius Commission, online: Codex Alimentarius $<$ www.codexalimentarius.net $>$ [FAO]. 
the needed jurisprudence on sustainability in genetic and natural resources management without failing the WTO law of liberalization. It is, however, in such a rather sad and contradictory context that the WTO DSB is having full competence to receive, to hear and to settle all trade disputes including those with a more environmental component and background. This absurd choice of the International community is one of the worst contradictions of the human race, apparently mastering its own death with the full and naïve enjoyment of life's destruction on earth.

If the International community fails in creating suitable conditions for sustainability through a DSB on IEG, the sad consequences of biodiversity lost will be faced by our children and grand children. Our lack of political good will to pursue what has been agreed upon at the 1992 Rio earth summit has created negative effects in terms of sustainable development. At that summit, Parties to the UNEP were in accord when adopting Article 27 of the Convention on biological diversity (CBD). This article and its annexes provided an outstanding disputes resolution mechanism under the Convention and its Protocols. ${ }^{15}$ Since that, however, it has been a total silence on the matter of disputes settlement in sustainable development. This silence is one of the main reasons why the International community will be held responsible for any failure in the preservation of life on earth for future generations.

This current contribution on IEG towards and beyond Rio +20 wishes that the International community feels our great need for a WEO DSB to receive, hear, examine, and settle disputes that may arise in natural and genetic resources exploitation, utilization and management for the sake of sustainability. Such a mission will be conducted in accordance with the scientific norms, standards, limits of production or emission, methodologies and any other measured and established data by the WEO SB. Both the WEO SB and DSB will also assure the following up of decisions and judgements pronounced for the implementation of the WEO programs.

One could take confidence in the coming IEG reform since we have a manifest scientific potential and a promising institutional precedent for sustainability. Nevertheless, there is a missing key-condition to ensure sustainability: the political good will. In fact, political good will is the main potential hindrance to sustainability through the expected reform on IEG within the UN system. The solution to this potential difficulty can partly be found in the mutual support between the WTO and the WEO.

\section{A WTO DSB and a WEO SB as a Mutually Supportive Process for the Achievement of Sustainable Development}

This research is not promoting sustainability on IEG from a conflicting context between WTO and WEO. It is rather in favour of sustainability emerging through mutually supportiveness interactions between those two organizations in view of the achievement of sustainable development under political good will and global commitment to sustainability.

15 Convention on Biological Diversity, 5 June 1992, 1760 U.N.T.S. 79. 
The matter of political good will for sustainability in IEG is to be found in the willingness of the International community to face the reality of the urgency of finding sustainable ways to increase the profit in natural resources economy without creating the conditions of earth destruction. In other words, our current way of life standing - meaning the increasing of our financial wealth without concern for better conditions of life on earth for our children after us - is to be revisited. In such a perspective, it is only a complete change on the individual level that can bring a collective stand against non-sustainable economic actions.

The biodiversity lost trend around the world is so consistent that there is no doubt that it is now due time to integrate in our consciences the seriousness of the potential negative consequences of our non-sustainable behaviours and to stand therefore for sustainability. In this regard, our way of doing business should also be revisited when necessary because "a focus on the political economy of environmental governance suggests that attention needs to be paid to the interactions between policies and economy [...] firms are working at national, regional, and international levels to influence policy on prominent environmental issues." 16 Likewise, "management of the environment is linked directly to, or in many cases is an integral part of, governance of international production and finance, international trade and transports." ${ }^{17}$ In fact, the environment and prosperity and/or development should go together in a sustainable way to help us to leave a habitable earth to the future generations. I view of their participation to the Global environment governance forum of 2009 in Glion, Switzerland, a group of Swiss representatives of the civil society stated in their paper that economic development should be ecologically viable and that environmental protection does not preclude development. ${ }^{18}$ The contribution of the civil society among other stakeholders is more needed because "international governance can only be effective if it is integrated into local, national, and regional governance structures which encompass governments as well as civil society and the business sector[... $]^{\prime 19}$

The most problematic impact of the current opposition between environmental restrictions and prosperity/development in the multilateral negotiations scene explains the ongoing discussions on IEG reform. It has been said about such an opposition and in connexion with international environmental governance that "our planet still lacks effective global environmental governance. During the same period, the world trading system succeeded in rationalizing and strengthening its institutional

16 Levy, supra note 13.

17 Helge Hveem, "Global Governance and the Comparative Political Advantage of Regional Cooperation", in Diana Tussie, ed., The Environment and International Trade Negotiations; Developing Countries Stakes, (Ottawa: International Development Research Centre, 1999) at p.134.

18 Maria Ivanova, "The Politics of Policy: Options for Reforming Global Environmental Governance" paper prepared for the Global Environmental Governance Forum: "Reflections on the Past, Moving into the Future", June 28 - July 2, 2009 in Glion, Switzerland.

19 Akiko Domoto, "International Environmental Governance: Its Impact on Social and Human Development", in Hans Van Ginkel, ed., Human Development and the Environment; Challenges for the United Nations in the New Millennium Series, (New York: United Nations University Press, 2001) at p. 293. 
foundation." 20 WTO adepts for free trade and UNEP adepts for sustainable development are lost in a game that has a heavy cost: destruction of life on earth for future generations after us.

Therefore, this contribution on sustainability for IEG towards and beyond Rio +20 invites us all to commune with the urgency of finding a mutually supportive strategy between WTO and WEO for the sustainability sake. Rio +20 must be the opportunity for the International community to set up the road to a WEO with a scientific body and a DSB to handle environmental matters where WTO competence is limited, but with the collaboration of this last organization where needed.

There is a great need for a WEO which will increase visibility, status independence, authority, financial potential and strength to the environmental cause. Such a move may be what it takes to find a permanent cooperative strategy to settle once for all mutual supportive policies between WTO and WEO for the sake of sustainability and preservation of life on earth for future generations. In this regard, M. Renato Ruggiero, who was the WTO Director general in 1999, stated that "to strengthen the bridge between trade and the environment, the bridge needs two pillars: a World trade organization and a World environment organization.,"21

The mutual supportiveness between international trade treaties and international environmental treaties for the achieving of sustainable development has been adopted in the preamble of the Cartagena Protocol on biosafety as follow: "Recognizing that trade and environment agreements should be mutually supportive with a view to achieving sustainable development." ${ }^{22}$ Here again, the International community has a normative provision to work on. Therefore, any failure to build mutually supportive policy between WTO and WEO in view of sustainability will be interpreted as a lack of political good will and a lack of willingness to strive for a sustainably brighter future on earth for future generations. It has been noticed adequately in the context of negotiations on environmental issues that "the availability of arrangements that all participants can accept as equitable (rather than efficient) is necessary for institutional bargaining to succeed [...] probability of success in institutional bargaining rises when clear-cut and effective compliance mechanisms are available." 23

No doubt that the International community needs political good will and global commitment to sustainability among States to produce the needed sustainability in the coming reform on IEG within the UN system.

20 Steve Charnovitz, "Toward a World Environment Organization; Reflections Upon a Vital Debate", in Frank Biermann \& Steffen Bauereds, A World Environment Organization; Solution or Threat for Effective International Environmental Governance? (Burlington: Ashgate Publishing Limited, 2005) at p. 87 [Charnovitz].

${ }_{21}$ Alison L. Hoare, and Ricard G. Tarasofsky, "International Environment Governance", The Royal Institute of International Affairs, London, 2008 at pp. 24-26.

22 Secretariat of the Convention on Biological Diversity, Cartagena Protocol on Biosafety to the Convention on Biological Diversity, Text and Annexes, (Montreal: Secretariat of the Convention on Biological Diversity, 2000) at p. 2.

23 Oran R. Young, "The Politics of International Regimes Formation: Managing Natural Resources and the Environment", in Peter M. Haas, eds., International Environmental Governance (Burlington: University of Massachusetts-Amherst, Ashgate Publishing Company, 2008) at pp. 108-110. 


\section{SUGGESTIONS OF A TIMING AND OPTIONS SCHEDULE FOR MULTILATERAL NEGOTIATIONS IN VIEW OF A WEO ESTABLISHENT BEYOUND RIO + 20}

The political goodwill appears to be the basis of any practical and perennial stand for IEG reform in view of sustainability within the International community. French President, Nicolas Sarkozy has been actively calling for the establishment of a WEO for the last years. He is backed up on this by Angela Merkel, UN General secretary, Ban Ki-moon and the European Union (EU). ${ }^{24}$ Obviously, according to the Agence France-Presse, President Sarkozy is not the first french President to call for the creation of a world organization dedicated to the environment. Before him, President Chirac did it in May 2006 during the UE-America summit. It was on that event that this former french President spoke on the necessity of a world organization dedicated to the environment. ${ }^{25}$ Before them, however, other heads of countries and high-level representatives of countries did expressed similar thought even though in more general terms. In fact, we have been reminded that "the idea of bolstering international environmental governance by centralizing the current system under one umbrella institution [...] received important backing in June 1997, at the United Nations General assembly special session, when Germany's Federal Chancellor Helmut Kohl, Brazil's President Fernando Henrique Cardoso, South Africa's deputy President Thabo M. Mbeki and Singapore's Prime-minister Goh Chok Tong, joined together in a 'Declaration' for a Global initiative on Sustainable development, [...] the establishment of a Global environmental umbrella organization for the UN..."26

There is, then, a potential of political goodwill to build upon by the Consultative group of ministers and/or high-level representatives on IEG. It is hoped that the consultative group will be, at the end of the process, in a position to be able to convince UNEP Parties at Rio +20 of the necessity and urgency of having a WEO in the UN system to better face the current administrative challenges in IEG. Moreover, the Consultative group is not content with such a potential achievement. The co-chairs of the group namely Mrs Paula Lehtomäki, Minister of the environment of Finland and John Michuki, Kenyan minister of the environment, request a declaration from the United Nations General assembly to establish the WEO in the perspective of Rio +20 Earth environmental summit.

In this analysis, we also share the same confidence manifested by the Consultative group on IEG on the imminence of a WEO. Therefore, we take that liberty to suggest in the following section, potential options in terms of timing and schedule for multilateral negotiations in view of the WEO establishment for sustainability in the coming institutional reform toward and beyond Rio +20 .

\footnotetext{
24 Paola Messana, "Sarkozy: « il faut une organisation mondiale de l'environnement ».” A.F.P. 17 juillet 2009.

25 Ibid.

26 Charnovitz, supra note 20 at pp. 93-98.
} 


\section{A. A UN GA Declaration for the establishment of a WEO with a mandate to negotiate the DSB}

The present contribution suggests as a first option, the call for a United Nations General assembly declaration to establish the WEO with a clear mandate to negotiate charters for the Dispute settlement body and the Scientific body as technical bodies of WEO. In this perspective, the declaration will encourage the UNEP Parties to pursue the work started at the 1992 Rio Earth summit on disputes resolution under the CBD (article 27) ${ }^{27}$ after extending the scope of the disputes resolution mechanism to cover all the programs of the new WEO and sustainable development.

In fact, with Annex II of the convention, Article 27 of the CBD contains a more than appreciable legal material foundation to start and finalize multilateral negotiations for the establishment a DSB and a SB within a relatively short time.

\section{B. DSB and SB multilateral negotiations now and a declaration for WEO around Rio +25}

Considering the fact that multilateralism is gaining credibility among the International community because of the results on the biodiversity programs with three protocols to the $\mathrm{CBD}$, the Parties can easily choose to start without delay a round of multilateral negotiations to implement article 27 of the CBD after extending its scope to cover all UNEP and sustainable development programs and plan a UN GA declaration to establish the WEO at the end of such negotiations.

This last option has the advantage to get involved more smoothly those among the Parties that need to take more time to integrate the mutually supportive process between WTO agreements and International environmental agreements (EAs). However, this option will request a full commitment of the International community in a UN General assembly declaration to establish the WEO without any delay at the end of the DSB and the SB charters negotiations.

In conclusion to this section, let us state that both those two options can bring us towards a well functioning WEO around Rio +25 with an efficient administration and a strong and suitable institutional mechanism to ensure perennial sustainability in natural resources management and in genetic resources utilization.

$$
* * *
$$

This research aimed to bring further institutional elements to ensure sustainability in the coming administrative reform on International environmental governance within the UN system toward and beyond the 2012 Rio +20 summit. This paper showed that such expected administrative changes are expected for "there is

FAO, supra note 14. 
widespread consensus that the existing structure of international environmental management needs reform and strengthening [...] the current number of international environmental regimes is clearly too large."28

However, in order to ensure sustainability, the current study aimed to show that deeper changes, more than just administrative, should occur. For this purpose, it has been suggested the establishment of a WEO with a Scientific body dedicated to the measurement of sustainable indicators and with a WEO Disputes settlement body to follow-up the application and the implementation of such sustainable limits of production or emission, standards, rates, methodologies or any other kind of sustainable development indicators.

This research demonstrated in fact that by avoiding overlapping and contradicting agreements, the managerial reform would surely bring more administrative efficiency and more accountability with a better use of the GEF financial function. Nevertheless, the institutional part of the reform with the two proposed bodies will, on the other hand, bring more sustainability than ever before from now, towards and beyond the Rio +20 Earth summit.

This research concludes finally that the political good will from the Parties and a true stand for sustainable development of the International community are the main elements which are needed to seal in a perennial form the worldwide collective move towards a better life on earth for our children and theirs, through generations.

The 2012 (Rio +20 ) environmental earth summit has been presented here as a special opportunity to build a sustainable and a mutually supportive framework between trade agreements and international environmental treaties for life on earth. There is a hope indeed that the International community takes a stand for sustainability through mutually supportive interaction between trade agreements and IETs for the achievement of sustainable development by finalizing the current process toward the creation of a WEO with a scientific body and a disputes settlement body. However, this achievement will obviously just be the beginning of a number of huge challenges. Special working groups will be created to negotiate and adopt charters with details on the missions of both the WEO SB and the WEO DSB. From experience on multilateralism, we can say that the process may easily take many years considering the realities of the conflicting issues between trade and the environment.

There are also some other issues which are of a big interest through the process of the WEO establishment. Issues such as those are related to the creation of a plenary body in which member states will be represented and those regarding the mandate of an administrative body or secretariat can be mentioned as examples. These are more administrative issues which were not developed in this research for the sake of our initial purpose of focussing in institutional reform aspects for sustainability. These last issues will probably be addressed in due course or also by other academic specialists to share more on administrative trends on IEG reform beyond Rio +20 .

28 Konrad Von Moltke, "On Clustering International Environmental Agreements", in Gerd Winter, ed., Multilevel Governance of Global Environmental Change: Perspectives from Science, Sociology and the Law (Cambridge: Cambridge University Press, 2006) at pp. 409 and 410. 